Research, part of a Special Feature on Vulnerability and Adaptation to Oil Spills

\title{
Community Resilience and Oil Spills in Coastal Louisiana
}

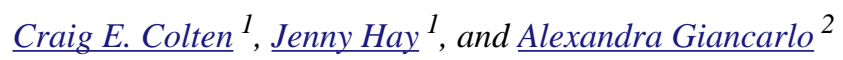

\begin{abstract}
The persistence of communities along Louisiana's coast, despite centuries of natural and technological hazard events, suggests an enduring resilience. This paper employs a comparative historical analysis to examine "inherent resilience," i.e., practices that natural resource-dependent residents deploy to cope with disruptions and that are retained in their collective memory. The analysis classifies activities taken in advance of and following a series of oil spills within Wilbanks' four elements of community resilience: anticipation, reduced vulnerability, response, and recovery. Comparing local inherent resilience to formal government and corporate resilience enables the identification of strengths and weaknesses of these different categories of resilience. It also helps answer the questions: What forms of inherent resilience capacity existed prior to the formulation of formal contingency plans? How have communities drawn upon their own capabilities to survive without the infusion of massive external assistance? Have externally managed contingency planning procedures integrated or bypassed inherent resilience?
\end{abstract}

Key Words: Gulf Coast; oil spills; resilience

\section{INTRODUCTION}

Since their founding, natural resource-dependent communities in Louisiana's coastal wetlands have had to cope with hurricanes, river floods, and more recently seasonal dead zones (hypoxic conditions) in the coastal waters. Over the years, Acadians, Isleños, Houma Indians, and Vietnamese have established themselves in precarious settings and have been culturally and economically marginalized. However, they have persisted and demonstrated resilience in the process. Residents' deep attachment to traditional livelihoods and their thorough embeddedness in community networks makes them reluctant to abandon their precarious home (Laska et al. 2005, Burley et al. 2007, and Colten 2011).

The 2010 BP oil release showcased another type of disruptive threat these communities face. Since offshore oil extraction began in the 1930s, these coastal residents have coped with spills and other forms of ecological damage caused by exploration and pipeline-related activities (Theriot 2011). Up until 1972, the response to these disruptions drew primarily on local capacities. Communities deployed largely ad hoc methods or drew on existing programs not intended for coping with hazards to respond to and recover from the full range of disruptions. The 1972 Clean Water Act authorized a federal oil contingency planning process that formalized both the short-term emergency response to oil spill incidents and the longer term recovery processes. In 1990, congress expanded upon the earlier legislation with the Oil Pollution Act that established procedures for the preparation and maintenance of plans, at multiple levels, for controlling oil releases and restoring ecological and social communities following incidents (Ramseur 2010). These plans place a premium on swift response to the emergency stage of a release and the restoration of natural resources, while also seeking to sustain a degree of preparedness between major oil spills. Critics, however, argue that these plans sometimes contribute to complacency and undermine effective preparations and responses (Boehlert 1989). Also, it is important to consider how well these plans engage with resilience built up over the last few centuries.

In this paper we will consider community resilience (Wilbanks 2008) as exhibited by local communities, government bodies, and corporate actors who have had to contend with major oil spills in the Gulf of Mexico. In particular, we will examine the relationship between inherent community resilience, or locally based capacities to cope with disruption, and formalized contingency plans. ${ }^{[1]}$ Our intent is to answer several fundamental questions: What forms of inherent resilience capacity existed prior to the formulation of formal contingency plans? How have communities drawn upon their own capabilities to survive without the infusion of massive external assistance? Have externally managed contingency planning procedures integrated with or bypassed inherent resilience?

\section{IDENTIFYING RESILIENCE}

Community members exhibit coping mechanisms through a set of adaptations and adjustments that enable groups to endure disruptive events (Adger 2000, Adger et al. 2005, Smit and Wandell 2006). Typically, these adaptations do not alter the social-ecological relationships, but neither do they guarantee continuity of local society. Nonetheless, they enable a community to persist, even if modified over time. We are primarily concerned with what we refer to as "inherent resilience," i.e., practices that natural resource-dependent residents deploy to cope with disruptions and that are retained in their collective memory. Among these are the ability to pursue natural resources in alternate areas, to shift the object of natural resource collection, to draw on kin and local social networks to respond to disruptions, and to seek economic relief through existing programs such as unemployment compensation and law suits (Table 1). This type of resilience 
stands in contrast to an increasing number of formalized, deliberate, resilience-directed government and private sector practices that are mobilized by the public safety officials charged with overseeing responses and recovery to disruptions. Oil spill contingency plans are one such formal structure (Colten 2011, Colten and Giancarlo 2011).

Table 1. All-hazards inherent resilience before 1970.

\begin{tabular}{llll}
\hline \hline Anticipation & $\begin{array}{l}\text { Reduced } \\
\text { Vulnerability }\end{array}$ & Respond & Recovery \\
\hline relocate inland & relocate inland & $\begin{array}{l}\text { shift fisheries } \\
\text { to safe areas }\end{array}$ & $\begin{array}{l}\text { local fishing/ } \\
\text { hunting season } \\
\text { limits }\end{array}$ \\
$\begin{array}{l}\text { request state } \\
\text { studies of } \\
\text { ecological } \\
\text { damage }\end{array}$ & $\begin{array}{l}\text { tainted catch } \\
\text { taingers }\end{array}$ & law suits \\
& $\begin{array}{l}\text { family aid } \\
\text { personal } \\
\text { economic } \\
\text { diversification } \\
\text { suppress }\end{array}$ & $\begin{array}{l}\text { family aid } \\
\text { file for }\end{array}$ \\
& negative news & $\begin{array}{l}\text { local funds for } \\
\text { restoring } \\
\text { fisheries } \\
\text { local funding to } \\
\text { rebuild houses }\end{array}$ \\
\hline
\end{tabular}

Sources: This table organizes oil spill related actions using Wilbanks' (2008) four elements of resilience. It was prepared using local ethnographic and disaster response literature and primary sources that document coping practices following past coastal disruptions. The sources include: Fogelman 1958, Bates et al. 1963, Plaquemines Parish Council Records 1970, St. Bernard Parish Council Records 1970, Comeaux 1972, Burley et al. 2007, Colten and Sumpter 2009, Burley 2010, Colten 2011, Colten and Giancarlo 2011, and Theriot 2011. Reviews of the following newspapers for their coverage of the spills also provided important historical information: Galveston Daily News, Houston Chronicle, Lake Charles American Press the New Orleans Times Picayune, and the Plaquemines Gazette.

Resilience literature, although attentive to traditional, locally based capacities, does not effectively distinguish between the multiple levels of resilience: personal, familial, local nongovernment, government (state and federal), and corporate. Each has different mechanisms for communicating and perpetuating resilience. Social memory is the repository of inherent resilience and is sustained in local networks, not formal documents and plans (Adger et al. 2005). Recovery after repeated batterings by hurricanes and oil spills, even before Civil Defense, Federal Emergency Management Agency (FEMA), or the national contingency planning process, demonstrates the existence of local inherent resilience that resides in the marginalized human communities of the Louisiana wetlands (Burley et al. 2007, Colten 2011). Social memory retains the basic ingredients that humans draw on for launching adaptations. Government and corporate plans depend on formal procedures.

Thomas Wilbanks (2008) defines resilient communities as those locales and regions that maintain four key elements that enable: (1) the ability to anticipate disruptive events, (2) the capability to respond to them effectively, (3) the mechanisms to recover from them equitably and efficiently, and take steps to (4) reduce vulnerabilities to future events. Long before oil extraction began along the Louisiana coast, communities faced hurricanes on a regular basis (Laska et al. 2005, Colten 2011). The persistence of communities in precarious locations is a clear indication of resilience that existed even before the term helped frame our understanding of the process (Table 1). Local fisherfolk harbor their shrimp boats in protected bays or "up the bayou" when tropical cyclones approach and most families draw on multiple, seasonal incomes to minimize the impact of a single disruptive event (Comeaux 1972). Entire communities have retreated inland in the face of storms and coastal land loss, such as Chenier Caminada relocating to Leeville after the 1893 hurricane (Burley 2010, Colten 2011). Family networks offer shelter and sustenance for those who are unable to continue their normal routines during and after disruptions (Fogelman 1958, Bates et al. 1963). Nonetheless, although community resilience may weaken with inland migration following hurricanes, fewer people are at risk and kin and ethnic networks that link coastal residents with inland neighbors are extended inland, toward areas a safer distance from the coast. Through social and family networks, individuals maintain access to shelters and resources during disruptions and other supportive mechanisms that come with such linkages (Fogelman 1958, Bates et al. 1963). These same networks enable the perpetuation of practices passed from parent to child.

Beyond traditional knowledge and kin networks, inherent resilience includes a range of practices that may draw on legal or other government services not intended to assist communities after a disruptive event. By filing suits using common law or drawing on unemployment programs not originally envisioned for oil spill recoveries, community members sustain themselves. Our analysis will search for the particular practices, including the adaptations of pre-existing legal and government services deployed by oil spill impacted communities that exemplify inherent resilience.

We will employ a comparative historical analysis to identify community resilience as reported in newspaper and trade journal accounts, litigation records, and government reports and hearings, to categorize post oil spill efforts within Wilbanks' four elements of resilience and classify these efforts as inherent or formal (government or corporate). Our intent is to identify the actions taken at the local level, independent of contingency planning, that emerged before and continued after 
formal procedures commenced. By tracing the perpetuation of local, inherent resilience capabilities, we will expose those vitally important local means for coping with disruptive events. Our method does not rely on common, systematic, and sometimes proxy metrics of resilience (Rose 2004, Tierney and Bruneau 2007). These sources play an important role in our understanding of resilience, but we have turned to historical sources that reveal human actions taken in the wake of disruptions. This offers a complementary view into the actual practices of communities.

A fundamental component of the current resilience-building effort in the U.S. relies on formal plans. The pervasiveness of this activity demanded that we consider its predecessors. Hence, we will identify government and corporate actions taken in advance of and following oil spills to document formalized resilience and classify them within Wilbanks' framework. In addition, we will review disaster response plans to determine if these formalized resilience-building documents engage or intersect with inherent resilience.

We selected two major oil spills in 1970 to represent the precontingency planning phase, and a tanker spill in 1984 that occurred after the initial Clean Water Act phase of contingency planning commenced. Finally, we followed a similar procedure for the post-1990 Oil Pollution Act reaction as reflected by actions following the $2010 \mathrm{BP}$ oil release. We were unable to take this final review to its conclusion because much of the response and recovery efforts are still very much underway. Nonetheless, we classify the preliminary efforts to identify areas of community resilience and their role in contingency planning in the two years following the event.

\section{CONTINGENCY PLANNING}

Following passage of the Federal Disaster Relief Act of 1950, Louisiana developed plans for disasters. In a series of regularly updated plans it sought to maintain readiness for a range of hazards, but not oil spills explicitly (Louisiana Civil Defense Agency 1950, 1959, 1963). These documents contained skeleton plans for responding to disruptions and restoring order by way of coordinating with federal agencies and also local governments. The plans explicitly empowered the Red Cross to dispense relief supplies at the local level, but did not incorporate family networks. Hurricane plans included evacuation plans, reflecting traditional practices such as movement to inland shelters.

Before 1972, Civil Defense Disaster Relief Plans provided the template for responding to major disruptions. States maintained and regularly updated these plans, and in Louisiana they focused on hurricanes and nuclear attacks. Despite their narrow scope, disaster plans provide the framework for formal responses (May 1985). At the federal level the U.S. Department of Interior maintained plans for responding to oil spills that emphasized emergency response and natural resource damage assessment, not human impacts. In effect, the human and ecological systems were largely decoupled. At the corporate level, industry responded to oil releases with fire suppression, well-capping, and spill clean-up techniques developed in the oil fields during the 20th century in a fairly systematic, although case-by-case manner.

The federal government called for oil spill contingency planning policies beginning with provisions in the 1972 Clean Water Act. This legislation framed responses at the "federal, regional, and area"[2] levels and emphasized Wilbanks' anticipation and response elements of resilience. It called for maintenance of multitiered federally coordinated plans for responding to oil releases. The Coast Guard's 1972 plan for coastal Louisiana outlined an integrated response through established government organizations with virtually no recognition of community or familial networks (USCG 1972). Corporations were also expected to prepare plans for their role in oil spill responses. The act set no specific criteria for state or local government plans, although coordination with the federal efforts was a fundamental expectation and Louisiana incorporated coordination procedures into its plans (Louisiana Office of Emergency Preparedness 1982, Louisiana 1996, Douligeris 1997).

Criticism of the initial federal contingency planning legislation centered on the anticipation and response elements that proved to be inadequate during the 1989 Exxon Valdez incident. Contingency plans outlined steps to halt oil releases and specified measures to contain the spread of oil and to limit its impacts on marine and coastal environments.

Since the passage of the Oil Pollution Act in 1990, the response and recovery operations have increasingly extended assistance to human communities. There are now explicit provisions to attach liability to the responsible party for personal property losses, resource-based subsistence losses, and profit loss because of natural resource impacts (Ramseur 2010). Even within the revised process, initial expenditures and efforts focus on controlling the emergency event and tallying natural resource damages. During the emergency phase, communities still have to draw on their own resources.

\section{S OIL RELEASES AND RESILIENCE}

Two major drilling rig incidents threatened the Louisiana coast in 1970 before the federally mandated oil spill contingency plans. The first began on 10 February when a Chevron oil production platform erupted into a massive fire that took a month to extinguish. Situated about 45 miles east of Empire, Louisiana an estimated 1000 barrels of oil entered surrounding waters daily until crews capped the wells in late March. Trade literature characterized the event as "the largest oil spill in U. S. history" (Big Gulf oil spill 1970:78). The failure of "chokes" designed to close off oil flow during an emergency allowed crude to escape and prevented a swift termination of releases (Davis 1970a). During the calamity, Chevron argued that by allowing the fire to continue it reduced water pollution, 
suggesting there was little danger of oil spreading. The U.S. Department of Interior officials, however, reported a slick as early as 13 February (Davis 1970b). They also noted that a significant oyster production area was threatened, even though they had initially characterized leaks as insignificant (Davis 1970c).

In the interval between the fire's eruption and capping of the wells, oil slicks intermittently moved beyond containment devices toward the Louisiana shore or to the southwest. In less than a month, oil had reached Breton Island, 10 miles from the platform, and Chevron dispatched crews to clean up its beach (NOAA 1970a). A subsequent federal inquiry concluded that favorable seasonal winds and the large spring discharge from the Mississippi River reduced shoreward drift of oil. In fact, the flow from the Mississippi produced a "fresh water barrier" that minimized damage (Pecora 1970:14).

Corporate and government entities reported no significant damage to natural resources, and largely ignored impacts on the human community. Chevron officials proclaimed "Not one bird has received any injury. Not one drop of oil has entered any commercial oyster bed" (After 7 long weeks ... 1970:61). Federal investigators concluded that "little damage appeared to have occurred to beaches, wildlife, or marine life" (NOAA 1970b) and a U.S. Environmental Protection Agency investigation concluded that the spill caused few acute biological problems (USEPA 1971). State officials tested oysters in the threatened area and concluded that they had suffered no damage and posed no threat to consumers (Wildlife unit ... 1970). There were, however, reports that the market for Louisiana shrimp declined because of consumer uncertainty (USEPA 1971). With negligible documented impacts on marine and coastal life, cascading consequences in the human community would have been minimal (Machlis and McNutt 2010). However, the Department of the Interior ordered all of the Chevron wells closed until safety inspections were conducted, and this sparked a public outcry and appeals for the resumption of leasing reflecting impacts to the local economy otherwise not considered (Drilling interest ... 1970, End lease renewal ... 1970). Concluding that there was negligible natural resource damage, government and corporate officials did not inquire with community groups and bypassed inherent resilience networks.

The formal responses to this spill arose from the corporate and federal and state governments. Responsibility for controlling the fire and oil releases fell on Chevron, the platform operator. It assembled specialists to fight the fire, cap the wells, and clean up oiled beaches. Department of Interior officials representing wildlife, marine resources, and mineral resources agencies monitored the slicks radiating from the release site, voiced concern with threatened oyster production areas, and participated in sampling programs to assess damages. There was virtually no reporting on how the oyster fishing communities fared. A review of oyster and shrimp landings statewide for 1970 does not reveal direct impacts (U.S. Department of Commerce 1968-1972). However, shrimp fishermen filed suit against Chevron, seeking up to US\$75 million in damages if shrimp spawning grounds suffered longterm damage (Oilman to face ... 1970). Seeking a legal remedy for long-term damages seemed to be the primary tool local communities deployed to recover from economic losses. The local parish council passed a defiant resolution claiming that the oil spill was not a disaster and that federally permitted river pollution posed a greater threat to local fisheries (Plaquemines Parish Council 1970). Additionally, the U.S. Department of Justice convened a federal grand jury to investigate potential violations of offshore drilling regulations (Oilman to face ... 1970). Inherent resilience appeared through the shrimpers' law suit and is reflected by the continuation of coastal fisheries (Table 2). The formal responses did not integrate community concerns or practices.

The second 1970 spill occurred on a Shell platform in Bay Marchand about 10 miles south of Timbalier Bay. After an explosion, a fire engulfed the platform on 1 December, killed two workers, and injured another 57 . The blaze continued into March (Edmiston 1971, NOAA 1970c). Its intensity delayed capping the wells, although oil flow had been reduced to 20 barrels per day by 16 April, 1971 when crews finally closed the wells. A slick stayed within a six-mile radius of the site, although oil reached the recreational beaches of Grand Isle. Shell crews cleaned up 600 gallons of emulsion from the beaches there in January (NOAA 1970d). An assessment of the spill on marine and coastal life concluded that hydrocarbons settled to the sea bed and produced serious stress among gastropods and other immobile species, and low fish populations surrounding the platform suggested additional stress to marine life (Resources Technology Corporation 1972).

Despite the casualties and the persistence of the release, virtually no reporting on impacts to the human community appeared in news accounts and there is no indication that corporate or government bodies interacted with kin or local social groups. The fact that the fire and oil release occurred during the winter months minimized disruption to Grand Isle tourism, but the nearby bays and open waters are prime shrimping areas and contain valuable commercial oyster beds. Statewide and regional shrimp and oyster harvests reflected no serious decline, partly because of the timing of the event (U.S. Department of Commerce 1965-1973). Nonetheless, it is likely cascading impacts followed this event. When a much smaller oil spill occurred in late 1969 , a state official reported that 12 oystermen were forced out of business because dealers would not purchase their catch for fear of contamination. The same official also exposed a probable factor for the absence of news reports on impacts to the fisheries. He asked the reporter to "suppress" the news and stated that "We don't like 
Table 2. Pre-1972 oil spill resilience.

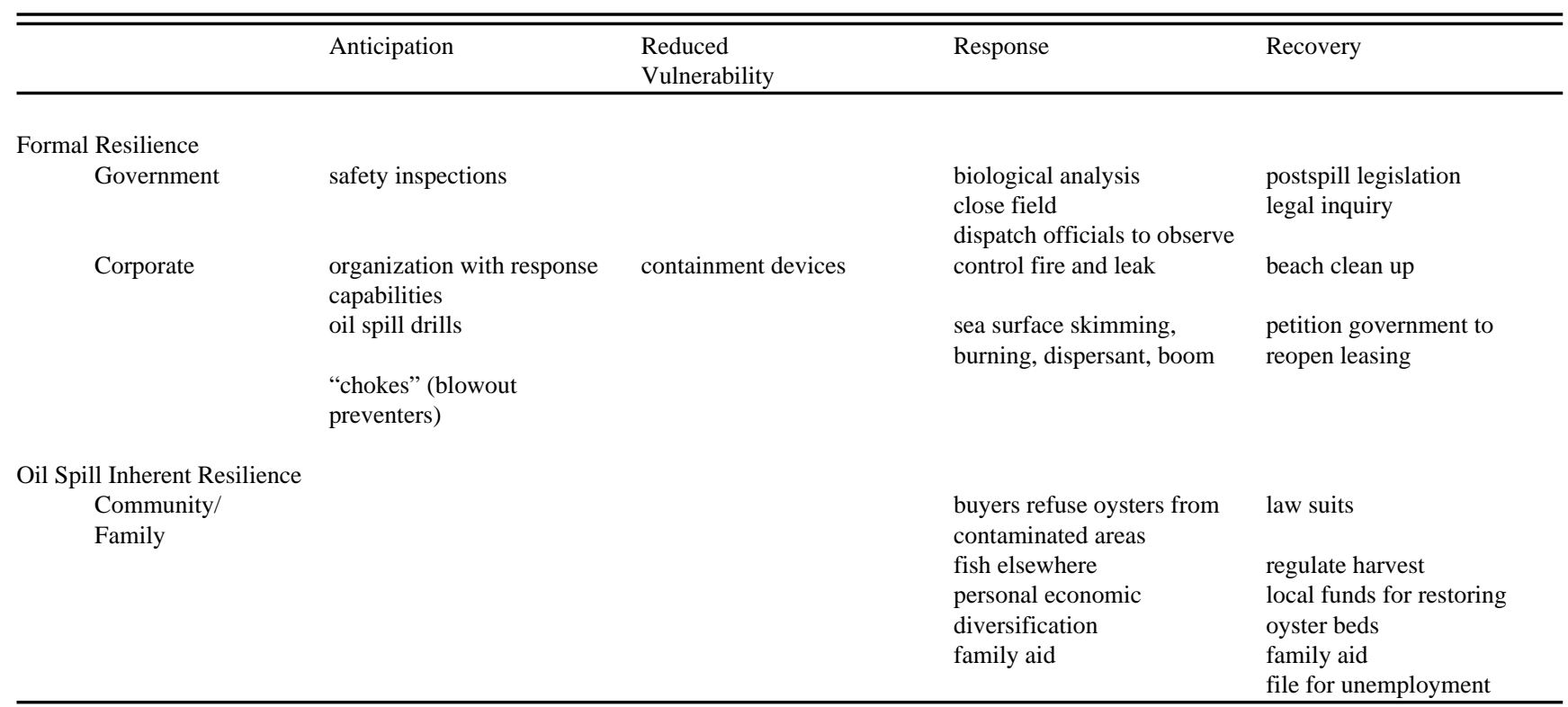

Sources: This table relies on sources cited in the text and organizes oil spill related actions according to Wilbanks' (2008) four elements of resilience.

to put this publicity out" (Oyster fishing ... 1970:16) out of concern that the public would overreact, refuse to buy Louisiana oysters, and substitute bivalves from Chesapeake Bay. Indeed, the Louisiana Wild Life and Fisheries annual report makes no mention of the two 1970 spills (Louisiana Wild Life and Fisheries Commission 1971). A local business man also vehemently downplayed the release and claimed that the benefits of the industry offset environmental risks (Pollution reaction ... 1970).

Documentation of inherent resilience in this instance is thin, but traditional practices such as shifting the location of fishing activities, turning to other resource-collecting practices, and relying on family aid enabled local fisheries and recreation businesses to continue in succeeding years (Fogelman 1958, Bates et al. 1963, Comeaux 1972, Burley et al. 2007). Newspaper accounts also reveal actions taken by a local fishermen's association to initiate legal action (Threaten court action ... 1971). Shell's corporate response mirrored the actions taken by Chevron previously. It contracted with specialists or dispatched its own personnel to control the fire, cap the wells, and clean up oil that reached the shore. Federal officials coordinated with state workers to document impacts to marine life (Table 2).

Following the two 1970s spills, federal authorities approved a plan for oil producing companies to cooperatively fund and maintain a spill response company, Clean Gulf Associates. It was to maintain equipment on standby along the Gulf Coast to respond to future releases. This arrangement, an example of both anticipation and reduction, sought to minimize costs to individual companies and to prevent subsequent failures to maintain equipment in a state of readiness. Oil producers also conducted practice maneuvers to ensure they were prepared for future events (Davis 1972, 1973).

\section{ALVENUS TANKER RELEASE 1984}

The British tanker M/T Alvenus suffered a structural failure in the Calcasieu Channel about 11 miles southeast of Cameron, Louisiana on 30 July, 1984. The failure ruptured one of the ship's storage holds and released nearly 66,000 barrels of oil into the Gulf of Mexico. Prevailing winds and currents drove the crude toward Galveston, Texas about 70 miles to the west. Clean Gulf Associates was not equipped to deal with a massive at-sea spill and did not have resources staged nearby. Thus, inadequate preparations, despite mandated contingency plans, delayed the emergency response (NOAA 1984a). Eventually responders, guided by the U.S. Coast Guard's contingency plan, stabilized the tanker, removed oil from the undamaged holds, and halted oil releases. NOAA broadcast warnings to shrimpers to avoid the area and other federal agencies began monitoring seafood to prevent tainted shrimp from reaching the market and impacting consumer confidence (NOAA 1984b).

By 4 August, oil had washed ashore along Texas beaches stretching from the Louisiana state line to 10 miles southwest of Galveston, and local officials closed public beaches and commenced clean-up operations (Coast Guard surveys ... 1984, Sun devotees ... 1984). As part of the response, crews placed booms across the mouth of Galveston Bay to protect marine life there. Despite initial projections of a massive 
tourism decline, subsequent tabulations indicated only a serious loss for the weekend immediately following the release (Sieghart 1984). A federal official proclaimed there was minimal impact to shrimp fishing because the oil followed a trajectory near the shore and most shrimping took place in deeper waters (Texas spill ... 1984). After about a month, reports suggested hotels were full for the Labor Day weekend (Galveston tourists ... 1984). Thus, early assessments suggested minimal local economic impacts.

Postspill testimony suggested that contingency planning framed by the Clean Water Act of 1972, augmented by recent experience with the Ixtoc oil release in 1979, enabled Galveston government officials to coordinate clean-up activities during the emergency response (U.S. Senate 1980). Despite optimistic news reports of minimal damage to fisheries and tourism, the long-term recovery produced a series of law suits filed by shrimpers, property owners, Galveston County, and the State of Texas. Legal actions by ad hoc community groups indicate that there were damages and that the existing policy framework was inadequate in the eyes of local entities (Lloyd's Leasing v. Conoco 1989, Lloyd's Leasing v. Bates 1990). There were no formal closures of marine fisheries and fishermen had to either move to uncontaminated waters, or risk damage to their equipment or rejection of tainted catches at the marketplace. Beaches remained open; however, despite optimistic claims about little disruption, tourism businesses sustained damages and losses from the oil that landed on the beaches. Federal policy at the time contained no explicit procedures to ensure damage payment to impacted businesses. Resilience resided in the ability of fishermen and tourism businesses to draw on their own resources to endure the disruption.

A sizable number of fishermen worked through informal commercial and ethnic networks to seek common-law compensation for damages. In a series of affidavits, shrimpers claimed that the oil spill caught them by surprise during the peak white shrimp season. While fishing near the shore, where they anticipated the best catches, they sustained damages to their boats and nets. The presence of oil compelled them to fish farther off shore, which they asserted was not economically viable. Thus, the spill disrupted their operations between July and October that year (Lloyd's Leasing v. Bates 1988). As many as 1880 fishermen from three Texas counties, plus some Louisiana fishermen, joined the class action suit, and an additional 240 Vietnamese fishermen from Port Arthur attempted to join the group (Lloyd's Leasing v. Conoco v. Bates 1989). In a related, but separate suit tourism-oriented business owners sought compensation for property damage resulting from guests tracking oil from the beach into their facilities. Ultimately the court denied the suit on the basis of the tanker operator's inability to foresee the potential harm (Lloyd's Leasing v. Conoco 1989). Although the numerous suits for damages produced no awards for the plaintiffs, Texas secured a US\$1.1 million settlement in 1991 (Owner pays ... 1991). Although contingency planning covered the initial, albeit delayed, emergency phase along with postspill environmental assessment, the raft of law suits suggest government and corporate responses did not adequately address the disruptions to local communities. Community members worked through social networks and common-law remedies to recover.

Once again, inherent resilience was evident in the networks that assembled large numbers of fisherfolk and tourism businesses into groups filing class-action law suits (Table 3). Mobilization by fisherfolk and tourism businesses through local, social networks exemplifies the adaptation of preexisting mechanisms to an unanticipated disruption. Furthermore, none of the lawsuits drew on measures outlined in contingency plans or employed oil spill specific legal remedies. Instead they adapted existing common-law remedies. The inadequate preparations by the industry response group and long-distance spread of oil from Louisiana to Texas demonstrates contingency plans were insufficient to handle the emergency stage of the release and resilience resided in local community actions. Without a place in the formal planning process, there was considerable mobilization of local capacities even if the impacted communities did not achieve their objectives.

\section{THE BP OIL RELEASE AND INHERENT RESILIENCE}

The 1970s oil spills did not trigger Louisiana's emergency response apparatus, and even by the time of the Alvenus oil spill in 1984 when preparedness plans anticipated oil releases as a potential hazard, state officials did little (Louisiana Office of Emergency Preparedness 1982). Like its predecessors, the 1982 document provided a chain-of-command organizational structure and delegated local responsibilities to local government and the Red Cross. Designated short-term evacuation routes remained a central part of planning, but it excluded family/kin networks and traditional economic practices.

When the BP/Macondo/Deepwater Horizon event occurred in 2010, federal policies had undergone considerable adjustment. Following the Exxon Valdez oil release in Alaska in 1989, Congress passed the Oil Pollution Act (OPA) that strengthens federal authority to manage oil spill response operations, and requires vessel and platform operators to file detailed spill response plans. Further, it assigns state and federal natural resource agencies with the responsibility to assess damages and initiate restoration, rehabilitation, and replacement (Olney 1997). This act addresses both immediate, emergency responses and longer term natural resource restoration. The OPA significantly expands the range of damages for which responsible parties are liable, including loss of personal property and associated economic losses, along with 
Table 3. Post-1972 oil spill resilience.

\begin{tabular}{|c|c|c|c|c|}
\hline & Anticipation & $\begin{array}{l}\text { Reduced } \\
\text { Vulnerability }\end{array}$ & Response & Recovery \\
\hline \multicolumn{5}{|l|}{ Formal Resilience } \\
\hline Government & Contingency plans & close fisheries & $\begin{array}{l}\text { biological analysis } \\
\text { alternate employment } \\
\text { programs }\end{array}$ & $\begin{array}{l}\text { postspill legislation } \\
\text { compensation program }\end{array}$ \\
\hline & & monitor seafood quality & oversight of response & $\begin{array}{l}\text { NRDA (hold responsible } \\
\text { parties liable for costs) }\end{array}$ \\
\hline Corporate & $\begin{array}{l}\text { organization with response } \\
\text { capabilities }\end{array}$ & containment devices & $\begin{array}{l}\text { cap well, skimming, burning, } \\
\text { dispersant, boom }\end{array}$ & beach clean up \\
\hline \multicolumn{5}{|l|}{ Inherent Resilience } \\
\hline \multirow{2}{*}{$\begin{array}{l}\text { Community/ } \\
\text { Family }\end{array}$} & & & family aid & law suits \\
\hline & & & $\begin{array}{l}\text { fish elsewhere } \\
\text { personal economic } \\
\text { diversification } \\
\text { move up bayou }\end{array}$ & unemployment compensation \\
\hline
\end{tabular}

disruption of subsistence or income from damaged natural resources (Ramseur 2010). Thus in 2010, contingency planning included human communities, but the scale of preparations remained inadequate.

Louisiana's Oil Spill Contingency Plan (Louisiana 1996) specifies a long list of state responsibilities in the event of an oil release including state-federal coordination. It contains no recognition of the social networks and mobility mechanisms that have functioned effectively in the past to sustain inherent resilience. The state's plan illuminates how external expertise becomes the principal asset, overshadowing local expertise. In doing so, it ignores inherent resilience borne of centuries of coping with disruptive events.

In the wake of the $2010 \mathrm{BP}$ oil release, there was an expanding closure of fisheries areas in open waters and nearshore wetlands (Louisiana Department of Wildlife and Fisheries 2011, Upton 2011). Federal and state experts made the decisions, not local fisherfolk and wholesalers. Closures severely impacted catches and Louisiana landings dropped $32 \%$ (Upton 2011). Oyster beds suffered because of the freshwater released from the Mississippi to block oil slicks from impacting the coastal marshes. Federal programs provided opportunities for fisherfolk to earn a living through the Vessels of Opportunity and through the Gulf Coast Claims program. Tourism received substantial infusions of BP funds to promote recreational opportunities in the region (Gulf Coast Claims Facility, unpublished data).

The initial disruption to local communities was significant, but the flow of corporate and government funds through the emergency response provided the impacted communities with financial assistance to cope (Table 3). However, this is not inherent resilience. The Vessels of Opportunity and the Gulf Coast Claims processes did not operate through local kin/ social networks or promote traditional coping mechanisms during the emergency phase and increased local dependence on external funding. Early reports indicate the shrimp catch is down for 2011 and 2012. Resilience in terms of economic and public health recovery remains to be seen, although the fishing community's criticism of the payment programs has been shrill.

\section{CONCLUSIONS}

Louisiana's coastal communities have endured repeated disruptions in the form of hurricanes, floods, and oil spills. Following traumatic events there have been modest retreats from highly exposed locations, but for the most part the coastal economic activities and communities endure. Obviously, some fishing and tourism business owners have been able to recover from repeated disruptions, along with the normal vagaries of their respective trades, suggesting a degree of inherent resilience. Our comparative historical analysis has shown a range of inherent resilience capacities that have functioned largely in the response and recovery elements. Unlike formal plans, inherent resilience is virtually invisible in Wilbanks' anticipation and reduction elements. In sharp contrast, formal plans are heavily oriented toward anticipating events and reducing impacts, yet they do not always function effectively. Our historical analysis shows a clear distinction between the elements of resilience that are sustained at the 
local level and the government/corporate level. Intimate local knowledge along with family and social networks provided the inherent resilience necessary to contend with ecological damages in the past.

Federal contingency planning since 1990 has expanded the outreach of compensation programs, but it has not directly engaged with the core components of inherent resilience we identified. Inherent resilience operates at a local level that is not readily revealed by the economic measures used to gauge the impacts of and recovery from hazard events. Consequently, it is easy for postevent inquiries to neglect these capacities. Furthermore, current contingency planning does little to reveal either the local or personal level of impacts and fails to recognize or operate through the local networks that can most effectively enhance inherent resilience. The distribution of massive sums of money through emergency programs redirects local efforts from restoring their own economies toward securing external funds. In effect, this process can contribute to an unraveling of local kin and social networks that have been central to community resilience in the past and fostering complacency at the local level. State and federal plans that fail to integrate inherent resilience capacities might strive to incorporate local mobility and familial networks in the future.

${ }^{[1]}$ We draw on Shirly Laska's (2008) concept of "essential resilience," but seek to emphasize the traditional practices and not the ideal outcome of resilience capacity building. We use inherent resilience as a subset of the broader and more inclusive term community resilience as defined by Wilbanks (2008).

[2] "Area" in this legislation was a territory that may have included portions of two states, but was larger than what we refer to as local.

Responses to this article can be read online at:

http://www.ecologyandsociety.org/voll7/iss3/art5/responses/

\section{Acknowledgments:}

The authors would like to gratefully acknowledge initial support from the U.S. Department of Interior, Strategic Sciences Working Group. The project described was supported by Award Number U19ES020676 from the National Institutes of Environmental Health Sciences. The content is solely the responsibility of the authors and does not necessarily represent the view of the National Institute of Environmental Health Sciences or the National Institutes of Health. We are also indebted to the editors and reviewers for their insightful and constructive comments on earlier drafts.

\section{LITERATURE CITED}

Adger, W. N. 2000. Social and ecological resilience: are they related? Progress in Human Geography 24:347-364. http://dx .doi.org/10.1191/030913200701540465

Adger, W. N., T. P. Hughes, C. Folke, S. R. Carpenter, and J. Rockström. 2005. Social-ecological resilience to coastal disasters. Science 309:1036-91039. http://dx.doi.org/10.1126/ science. 1112122

After 7 long weeks, end may be near for gulf spill. 1970. Oil and Gas Journal 68(13):60-62.

Bates, F. L., C. W. Fogelman, W. J. Parenton, R. H. Pittman, and G. S. Tracy. 1963. The social and psychological consequences of a natural disaster: a longitudinal study of Hurricane Audrey. National Academy of Sciences, Washington, D.C., USA.

Big Gulf oil spill. 1970. Oil and Gas Journal 68(14):78-79.

Boehlert, S. 1989. Hearing Before the Committee on Public Works and Transportation, National oil spill contingency planning and response capabilities. 101st Cong., $1^{\text {st }}$ Sess. Government Printing Office, Washington, D.C., USA.

Burley, D. M. 2010. Losing ground: identity and land loss in coastal Louisiana. University Press of Mississippi, Jackson, Mississippi, USA.

Burley, D., P. Jenkins, S. Laska, and T. Davis. 2007. Place attachment and environmental change in coastal Louisiana. Organization \& Environment 20:347-366. http://dx.doi.org/1 $\underline{0.1177 / 1086026607305739}$

Coast Guard surveys oil spill in Gulf. 1984. New York Times 7 August: A11.

Colten, C. E. 2011. Floods and inequitable responses: New Orleans before Katrina. Pages 113-129 in R. Roger and G. Massard-Guilbaud, editors. Environmental and social justice in the city: historical perspectives. White Horse Press, Cambridge, UK.

Colten, C. E., and A. Giancarlo. 2011. Losing resilience on the Gulf Coast: hurricanes and social memory. Environment: Science and Policy for Sustainable Development 53:6-19.

Colten, C. E., and A. R. Sumpter. 2009. Social memory and resilience in New Orleans. Natural Hazards 48:355-364. http ://dx.doi.org/10.1007/s11069-008-9267-X

Comeaux, M. 1972. Atchafalaya swamp life: settlement and folk occupations. Geoscience and Man 2:1-100.

Davis, W. J. 1970a. Gulf rigs fire rages. New Orleans TimesPicayune, 11 February.

Davis, W. J. 1970b. Well cap work start nears. New Orleans Times-Picayune, 13 February. 
Davis, W. J. 1970c. Oil fire rages off La. Coast. New Orleans Times-Picayune, 14 February.

Davis, W. J. 1972. Stand-by units to guard gulf. New Orleans Times-Picayune, 3 June.

Davis, W. J. 1973. Gulf cleanup equipment will be shown to public. New Orleans Times-Picayune, 8 August.

Douligeris, C. A. 1997. Study of Gulf Coast oil spill contingency plans with respect to remediation and restoration: final report, technical report 90-002. U.S. Army Corps of Engineers, Florida Sea Grant Office, Gainesville, Florida, USA.

Drilling interest exceeds spill fear, says Glasgow. 1970. New Orleans Times-Picayune, 5 April.

Edmiston, K. 1971. Shell fire dying peacefully. Oil Industry 6:34-41.

End lease renewal hearings: ninety percent urge that leasing be started again. 1970. The Plaquemines Gazette 24 July.

Fogelman, C. W. 1958. Family and community in disaster: a socio-psychological study of the effects of a major disaster upon individuals and groups within the impact area. Dissertation. Louisiana State University, Baton Rouge, Louisiana, USA.

Galveston tourists return. 1984. Lake Charles American Press, 21 August.

Laska, S. 2008. The "mother of all Rorschachs": Katrina recovery in New Orleans. Sociological Inquiry 78:580-591. http://dx.doi.org/10.1111/j.1475-682X.2008.00262.x

Laska, S., G. Woodell, R. Hagelman, R. Gramling, and M. T. Farris. 2005. At risk: the human, community and infrastructure resources of coastal Louisiana. Journal of Coastal Research 44:90-111.

Lloyd's Leasing v. Bates. 1988. Affidavits of shrimp fishermen. U.S. Court of Appeals, Fifth Circuit, Case file 88-2450. New Orleans, Louisiana, USA.

Lloyd's Leasing v. Bates. 1990902 F.2nd 368.

Lloyd's Leasing v. Conoco. 1989. 868 F.2d 1447.

Lloyd's Leasing v. Conoco v. Bates. 1989. Appellants' Brief. U.S. Court of Appeals, Fifth Circuit, Case file 89-2310. New Orleans, Louisiana, USA.

Louisiana Civil Defense Agency. 1950. Louisiana civil defense plan. Louisiana disaster relief plan. Louisiana Department of Military Affairs, Baton Rouge, Louisiana USA.

Louisiana Civil Defense Agency. 1959. State of Louisiana natural disaster relief plan. Louisiana Department of Military Affairs, Baton Rouge, Louisiana USA.
Louisiana Civil Defense Agency. 1963. Preparedness plan for emergency operation. Louisiana Department of Military Affairs, Baton Rouge, Louisiana USA.

Louisiana Department of Wild Life and Fisheries. 2011. LDWF announces major commercial fishing reopening. LDWF, Baton Rouge, Louisiana, USA. [online] URL: http:// www.wlf.louisiana.gov/news/33992

Louisiana Office of Emergency Preparedness. 1982. State of Louisiana disaster preparedness plan. Louisiana Department of Public Safety, Baton Rouge, Louisiana USA.

Louisiana Wild Life and Fisheries Commission. 1971. Biennial Report, 1970-1971. Louisiana Wild Life and Fisheries Commission, Baton Rouge, Louisiana, USA.

Louisiana, State of. 1996. Oil spill contingency plan. Louisiana Oil Spill Coordinator's Office, Baton Rouge, Louisiana, USA.

Machlis, G. E., and M. K. McNutt. 2010. Scenario-building for the Deepwater Horizon oil spill. Science 329:1018-1019. http://dx.doi.org/10.1126/science.1195382

May, P. 1985. Recovering from catastrophes: federal disaster policy and politics. Greenwood, Westport, Connecticut, USA.

National Oceanic and Atmospheric Administration (NOAA). 1970a. Incident news: Chevron main pass block 41. NOAA, Washington, D.C., USA. [online] URL: http://www.incidentn ews.gov/incident/6209

National Oceanic and Atmospheric Administration (NOAA). 1970d. Incident news: countermeasures/mitigation. NOAA, Washington, D.C., USA. [online] URL: http://www.incidentn ews.gov/entry/514083

National Oceanic and Atmospheric Administration (NOAA). 1970b. Incident news: other special interest issues-sampling. NOAA, Washington, D.C., USA. [online] URL: http://www. incidentnews.gov/entry/505834

National Oceanic and Atmospheric Administration (NOAA). 1970c. Incident news: Shell platform 26. NOAA, Washington, D.C., USA. [online] URL: http://www.incidentnews.gov/inci dent/6211

National Oceanic and Atmospheric Administration (NOAA). 1984b. Incident news: report - situation. NOAA, Washington, D.C., USA. [online] URL: http://www.incidentnews.gov/entr $\mathrm{y} / 509574$

National Oceanic and Atmospheric Administration (NOAA). 1984a. Incident news: USCG case history. NOAA, Washington, D.C., USA. [online] URL: http://www.incidentn ews.gov/entry/509572 
Oilman to face investigators. 1970. New Orleans TimesPicayune, 2 April.

Olney, A. P. 1997. Oil pollution act. Pages $161-195$ in T. F. P Sullivan, editor. Environmental law handbook. Government Institutes, Rockville, Maryland, USA.

Owner pays \$1 million in Alvenus suit. 1991. Galveston Daily News, 13 December.

Oyster fishing in bay suffers. 1970. New Orleans TimesPicayune, 6 January.

Pecora, W. T. Testimony. 1970. Hearing Before the U.S. Senate Commission on Insular Affairs: offshore oil platform fire and oil spill in the Gulf of Mexico. $91^{\text {st }}$ Cong., $2^{\text {nd }}$ Sess. Government Printing Office, Washington, D.C., USA.

Plaquemines Parish Council. 1970. Minutes of Meetings. Belle Chasse, Louisiana, USA.

Pollution reaction dropping. 1970. Houma Daily Courier, 20 December.

Ramseur, J. L. 2010. Oil spills in U.S. coastal waters: background, governance, and issues for congress. Congressional Research Service, Washington, D.C., USA.

Resources Technology Corporation. 1972. Studies and investigations of the fate and effect of the Shell oil spill, platform b, block 26, south Timbalier Bay. Resources Technology Corporation, for the U.S. Environmental Protection Agency, Office of Water Programs, Houston, Texas, USA.

Rose, A. 2004. Defining and measuring economic resilience to disaster. Disaster Prevention and Management 13:307-314. http://dx.doi.org/10.1108/09653560410556528

Saint Bernard Parish Police Jury. 1970. Minutes of Meetings. Chalmette, Louisiana, USA.

Sieghart, M. A. 1984. Slick didn't equal Texas' worst fears. Washington Post 6 August.

Smit, B., and J. Wandel. 2006. Adaptation, adaptive capacity and vulnerability. Global Environmental Change 16:282-292. http://dx.doi.org/10.1016/j.gloenvcha.2006.03.008

Sun devotees join workers on oily shore. 1984. New York Times, 7 August.

Texas spill not hurting shrimping. 1984. New Orleans TimesPicayune, 15 August.

Theriot, J. P. 2011. Building America's energy corridor: oil \& gas development and Louisiana's wetlands. Dissertation. University of Houston, Houston, Texas, USA.

Threaten court action against oil companies. 1971. Houma Daily Courier, 14 January.
Tierney, K., and M. Burneau. 2007. Conceptualizing and measuring resilience. TR News 250 May-June:14-17. [online] URL:http://onlinepubs.trb.org/onlinepubs/trnews/trnews250 p14-17. pdf

United States Coast Guard (USCG). 1972. Oil and hazardous substance pollution contingency plan. USCG, Eighth Coast Guard District, New Orleans, Louisiana, USA.

United States Department of Commerce. 1965-1973. Louisiana landings, annual summary. U.S. Department of Commerce, National Oceanic and Atmospheric Administration, Washington, D.C., USA.

United States Department of Commerce. 1968-1972. County Business Patterns: Louisiana: Jefferson Parish. U.S. Department of Commerce, Washington, D.C., USA.

United States Environmental Protection Agency (USEPA). 1971. Oil pollution incident: Platform Charlie, main pass block 41 Field Louisiana. U.S. Environmental Protection Agency, Water Quality Office, Washington, D.C., USA.

United States Senate, Committee on Commerce, Science, and Transportation. 1980. Campeche Oil Spill: Joint Hearing. $96^{\text {th }}$ Cong., $1^{\text {st }}$ Sess. Government Printing Office, Washington, D. C., USA.

Upton, H. F. 2011. The Deepwater Horizon oil spill and the Gulf of Mexico fishing industry. Congressional Research Service, Washington, D.C., USA.

Wilbanks, T. J. 2008. Enhancing the resilience of communities to natural and other hazards: what we know and what we can do. Natural Hazards Observer 32:10-11.

Wildlife unit proclaims no oil damage to sea life. 1970. New Orleans Times-Picayune, 19 March. 